World Lumen Congress 2021 | May 26-30, 2021 |

lasi, Romania

\title{
Optimizing Public Passenger Transport in Bucharest and the Metropolitan Area
}

\author{
Constantina CHIRIAC, Valeriu Stelian NIȚOI, Marius \\ GÎRTAN
}

https://doi.org/10.18662/wlc2021/12

How to cite: Chiriac, C., Niţoi, V. S., \& Gîrtan, M. (2021). Optimizing Public Passenger Transport in Bucharest and the Metropolitan Area. In A. Sandu (vol. ed.), Lumen Proceedings: Vol. 17 World Lumen Congress 2021 (pp. 93-120). Iasi, Romania: LUMEN Publishing House. https://doi.org/10.18662/wlc2021/12 


\title{
Optimizing Public Passenger Transport in Bucharest and the Metropolitan Area
}

\author{
Constantina CHIRIAC 1 , Valeriu Stelian NIȚOI², Marius GÎRTAN³
}

\begin{abstract}
The paper aims to be a model of analysis on passenger transport management for Bucharest and the metropolitan area, in order to stimulate the economic development of the city by supporting economic activities of local interest, by increasing the mobility of the transport system, economic activities that benefit local communities and that do not adversely affect people's health or the environment. The analysis presented proposes the use of geospatial information systems for urban traffic management and the construction of traffic simulation models.
\end{abstract}

Keywords: Information systems, urban traffic, public transport, durability, sustainability.

\section{Introduction}

The article is empirical research aiming to propose measures optimizing public passenger transport in Bucharest. It starts from the current situation of the public transport in Bucharest expecting to reach a level of public transport similar to Rome. The lack of interconnection between means of transport, information systems displaying the timetable of the surface public transport, their specific positions in traffic, the estimated time of arrival at the station, the degree of occupation of the transport systems and driving mode in the public transport for the drivers, are some of the measures that need to be implemented for an optimal public transport.

The main objective of the article is to underline the need of creating interconnections between public transport modes and reducing idle time while travelling.

Item 7 of the present article includes a case study of the transport modes used on a chosen route of approximately $12 \mathrm{~km}$, i.e. Gara de Nord - Piaţa Reşita, by using several modes of transport, as well as a chosen route from Rome on a

\footnotetext{
${ }^{1}$ University Politehnica of Bucharest, Doctoral School of Transport. Splaiul Independenței nr.313 Bucharest, Romania.e-mail: costina.barculet@yahoo.ro

${ }^{2}$ University Politehnica of Bucharest, Doctoral School of Transport. Splaiul Independenței nr.313 Bucharest, Romania. e-mail: nitoivs@yahoo.com

${ }^{3}$ University Politehnica of Bucharest, Doctoral School of Transport. Splaiul Independenței nr.313 Bucharest, Romania.e-mail: girtantoma@yahoo.com
} 
distance of $45 \mathrm{~km}$, i.e. Primavalle Pasquale II-Giardinetti.

Transport is one of the most important activities for human society, since it facilitates access to natural resources, it helps us save time when moving from one point to another, and it stimulates trade and makes it widely accessible. Human society, since ancient times, has developed continuously, through cooperation and intensification of its various economic and military branches, which has led to a permanent increase in transport needs.

From the 19th century onwards, transport in general and railway in particular, has developed rapidly, leading to technological innovations which were later implemented in the automotive industry with huge effects on the economy and society overall, as well as the environment.

This paper presents an analysis of passenger transport in Bucharest and its metropolitan area in order to better meet transport requirements in terms of speed, fuel consumption and reduction of pollution especially in large, densely populated cities.

The paper presents the consistency of transport, as well as some proposals for urban intermodal transport, necessary to shorten travel times, with implications in reducing energy consumption and pollution.

Advanced geospatial information systems technology also plays an important role in the efficient management of surface traffic, satisfying the needs of the urban economy and providing useful information to those concerned with solving the problems that arise in passenger transport.

Public transport in Bucharest was established in 1871 with the "Romanian Society of Trams", which operated horse-drawn trams.On December 9, 1894, the electric tram lines were launched, and the first trams ran between Obor and Cotroceni, on a $6.5 \mathrm{~km}$ distance.

Under Law No.15/1990, the Public Transport Enterprise has been transformed into the Transportation Autonomous Public Enterprise of Bucharest (RATB) which was maintained as such until 2018, when RATB changed its legal status from autonomous public enterprise to state-owned joint-stock company called the Bucharest Transport Company "STB" S.A.

The Bucharest Metropolitan Area was established in 2016, and it operates according to Law 351/2001 on the National Spatial Planning (Parliament of Romania, 2001).

Bucharest, the capital of Romania, is the most important commercial and industrial center of the country, and the localities around the city are part of its metropolitan area.

\section{Transport in Bucharest-Ilfov}

In 2017 the Inter-Community Development Association for Public Transport Bucharest Ilfov (ADTPBI) was established as a result of the association of the 42 local authorities in the Bucharest-Ilfov region, with the aim of establishing, organizing, regulating, operating, monitoring and jointly managing the Local Public Transport. The association developed, on the basis of the 
recommendations of the PMUD, the Integrated Programme of Public Passenger Transport - Bucharest-Ilfov. (Parliament of Romania, 2001).

Ilfov County comprises 40 territorial-administrative units:

1. 8 cities (Bragadiru, Buftea, Chitila, Magurele, Otopeni, Pantelimon, Popeşti-Leordeni and Voluntari).

2. 32 communes (1 Decembrie, Afumați, Baloteşti, Berceni, Brăneşti, Cernica, Chiajna, Ciolpani, Ciorogarla, Clinceni, Copaceni, Corbeanca, Cornetu, Dărăşti-Ilfov, Dascălu, Dobroeşti, Domneşti, Dragomirești-Vale, Găneasa, Glina, Grădiştea, Gruiu, Jilava, Moara Vlăsiei, Mogoşoaia, Nuci, Periş, Petrăchioaia, Snagov. (Fig:1. Bucharest metropolitan area).

The road network that starts from the centre of Bucharest and crosses the territory of Ilfov County ensures the transport of passengers, the shipment of goods inside the county, and road connections to all the cardinal points. These roads are insufficient and they are not correlated with the real estate development plan of Bucharest and Ilfov County. The lack of a continuous two-lane ring road adds to these shortcomings, as well as the need for building a second ring, which would allow increased mobility.

Transportation problems cannot be solved without a link between public transport and the tram, metro and rail networks with the ring road network.

Bucharest-Ilfov is one of the eight development regions of Romania, composed of Bucharest and Ilfov County, with a population of 2,121,794 (as of July 2018) and an area of $1,804 \mathrm{~km} 2$ (Agentia pentru Dezvoltare Regionala Bucuresti Ilfov, 2020).

It is the most developed region in Romania, with an extensive infrastructure network for multimodal public transport, but it suffers from a lack of funding for maintenance, and it is affected by a rigid separation between modes of transport at certain levels.

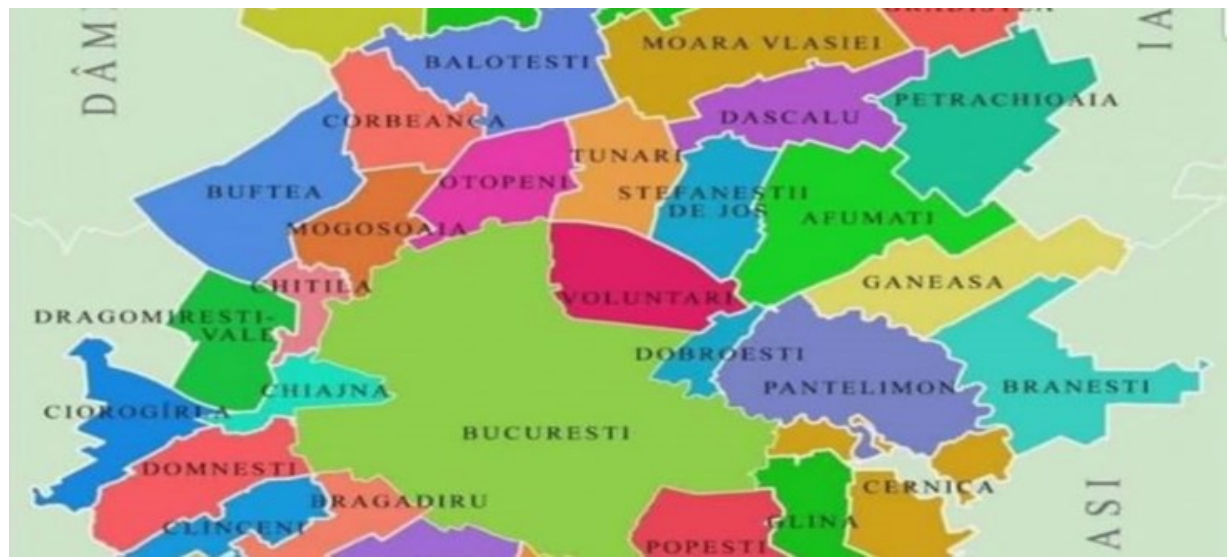

Fig. 1. Bucharest metropolitan area

Source: Google Maps

The economy of the region depends on the functions of the capital, the active population of the region being linked to the units operating here. 
The Bucharest-Ilfov region is the largest industrial agglomeration in Romania, where all industries are present. The trade sector, as well as storage, distribution, communal administration-household, construction industry have evolved rapidly, so that the region is moving away from the other regions in what concerns the level of development, despite the unfavorable geographical position, and it is being responsible for $25 \%$ of the total national economy.

The Bucharest-Ilfov region, through the municipality of Bucharest, is the most important national and international road-rail-air transport hub of the country, characterized by a high degree of accessibility, as it is located on two European multimodal corridors: European Priority Axis no. 4 (Nădlac-Constanța) and the European Priority Axis Giurgiu-Albita planned to be built in the near future, as well as in the vicinity of the Danube (European Priority Axis No 18). Air and multimodal accessibility is ensured by the international airport "Henri Coandă" (Otopeni), the largest international airport in Romania.

The transport service is a service of general economic and social interest, as a basis for the mobility and access to urban facilities, accessibility to social and health services for all categories of inhabitants in the territorial administrative area of ADTPBI (Agentia pentru Dezvoltare Regionala Bucuresti Ilfov, 2020).

The Bucharest - Ilfov region does not benefit from an extensive infrastructure network for multimodal public transport, and the lack of financing for maintenance or investments affects the modes of transport. The public transport system in Bucharest consists of buses, trolleybuses, trams, surface metro (managed by the City Hall of Bucharest), as well as subway lines and the suburban train from Gara de Nord to Otopeni Airport, managed by the Ministry of Transport, networks that need to be developed and harmonized with the city's development policy in order to increase mobility. The efficiency of public transport in Bucharest increases by the fact that, in addition to considerations or aspects related to the economy, traffic flow, rhythmic means of transport, there should be an interconnection of them with well-defined schedules for each type of transport, which are currently uncorrelated. The idea of interconnecting all means of transport satisfies as completely as possible the requirements of passengers by reducing travel time, and being able to travel from one point to another with several means of transport and reduce to a minimum the waiting time in exchange stations.

The Sustainable Urban Mobility Plan 2016-2030 does not solve the mobility problems in the Bucharest-Ilfov region, as there are not enough exits /entrances from/to Bucharest, because the real estate development was not based on an adequate design of the road infrastructure, the subway stations (especially) are not designed to reach the capital's ring road, the interchange points between the subway stations are few, and the tram infrastructure is not designed to ensure efficient connections with the underground and surface public transport. However, bus transport remains an important component of the public transport service, which will maintain the high level of air pollution and congestion of road infrastructure. There is no unitary intermodal concept between rail and public transport.

The subway is the fastest way to travel, followed by the tram, because both 
of them have their own dedicated tracks which are not affected by car traffic. Many people choose to use the subway because of shorter travel time and it is more efficient compared to surface transport modes. The increasing availability and speed of vehicles have had a beneficial effect on people's living conditions. This applies in particular to increased accessibility due to the daily use of private cars for commercial and leisure facilities. There are several measures to reduce the negative effects of using a private car, and an overall assessment of the current situation is needed to reduce the demand for car use for vehicles generating high levels of pollution.

In addition, in order to reduce traffic congestion, it is desirable to stop using the car in terms of when and where people drive, especially during peak hours in urban areas, or on major streets with regard to the reduction of congestion as well as the management of travel requests by the fact that the number of vehicles provided by the institutions managing public transport should be supplemented and the arrival time at the station should be as short as possible.

The concept of sustainability is far from being the basis of regional public transport policy and it is necessary to implement a digital public transport management system, one method being to reduce traffic jams by restricting the use of vehicles, introducing a toll for vehicles traveling in crowded areas should be applied during force majeure periods such as this year, when the pandemic imposed social distancing and this led to an increase in the use of personal cars, generating traffic jams and an increase in pollution due to polluting emissions. Personal mobility is provided by two public transport operators STB S.A. and S.C. Metrorex S.A. The surface transport in Bucharest is very crowded, the main cause being the increase in the use of private cars by the city inhabitants but also by people in transit.

Thus, if in previous years the number of passengers carried/year on all subway lines belonging to SC Metrorex SA reached 179,703 thousand / year, this year, the number of passengers carried was much lower, mainly due to the effects of the pandemic, which led to a temporary closure of schools, while many companies decided to allow work from home, so the number of passengers carried has dropped considerably, see Table 1 (Metrorex, 2018).

Table 1. Statistical period 2015-2018 in thousands of passengers carried by subway.

\begin{tabular}{cc}
\hline Year & Passengers carried \\
\hline 2015 & 174.830 \\
2016 & 179.120 \\
2017 & 178.850 \\
2018 & 179.703 \\
\hline
\end{tabular}

Source: Metrorex (2018). Raport Activitate METROREX

The proposed transport program for the current year for public transport provides for a total of 166 lines totalling an annual length of all means of transport of $88,129,567 \mathrm{~km}$ and includes the following categories of lines: 
- Trams -26 lines, 486 vehicles - km envisaged to be performed -19.609.937;

- Trolleybuses - 16 lines, 297 vehicles - km envisaged to be performed 10.066.654;

- Buses - 124 lines, 1147 vehicles - $\mathrm{km}$ envisaged to be performed $58,452,976$.

STB S.A., as a result of the SARS COV2 pandemic, temporarily reduced the number of vehicles in operation, which led to the failure to meet the estimated plan of number of kilometres to be covered. The length of the tramway network is composed of $141 \mathrm{~km}$ of double track and $282 \mathrm{~km}$ of single track. Out of the total of $141 \mathrm{~km}$ of double track, $30 \%$ are in poor condition, with significant wear, the cause being most of the times the large number of brakes due to congested road traffic, which in turn results in a large number of starts/stops generating high costs with energy and material stock. Traffic lines are frequently blocked by cars traffic, leading to massive disruptions to the traffic schedule, but also to an increase in the number of accidents, as many vehicles obstruct the tram way. In order to increase mobility in the capital and its area of influence, the first stage of integration between the two carriers (Metrorex and STB) is the introduction of a single ticket. This type of solution is advantageous for several trips by STB buses, trolleybuses and trams, as well as by subway. The solution should also be extended to the regional rail or metropolitan / regional transport system by creating a unitary public service package to be joined by all carriers. In case of a tram, maximum values of traction or speed are not always required.

When designing the vehicle, the functional and energy parameters depend on the force required at the wheel or the power required at $\mathrm{V}$ (speedmax) or V(speed min.) (Howlett \& Pudney, 1994).

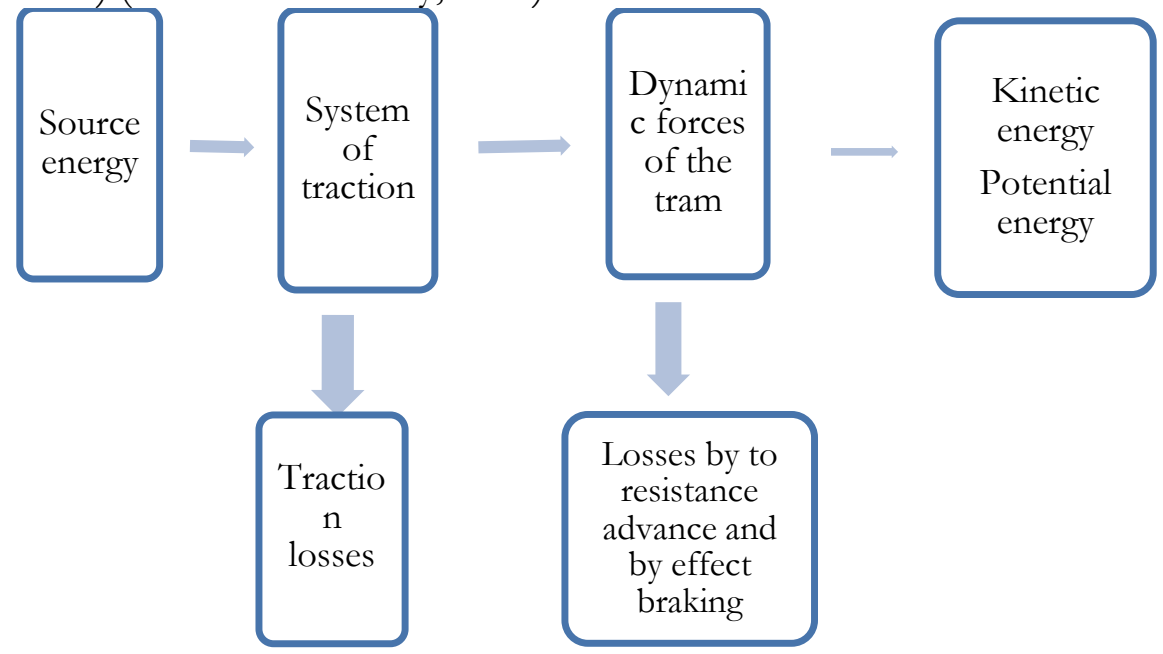

Fig. 2. Energy scheme for a tram.

Source: Howlett \& Pudney (1994)

Resistant forces occurring in bearings and alignment can be grouped into several categories. 
The resistances due to rolling and mechanical friction that occur during the movement of the tram are:

- resistance due to friction with bearings;

- resistance due to the rolling of the wheels on the rails; resistance due to deformations and shocks that occur between the running gear and rails;

- resistance due to slipping between the surfaces of the wheel and rail tires, resistance due to air pressure and friction, with or without wind, outdoors or in tunnels.

The resistance produced by the air during the movement of the vehicle is exerted on the front surface in the form of pressure, on the side faces in the form of friction and on the rear front surface in the form of depression. By analyzing the profile for the traffic of a tram, it is observed that for a distance between two stations " $\mathrm{X}$ " and the corresponding time to cover this distance "T", we have:

$\mathrm{u}(\mathrm{t})$ - the acceleration applied to the tram;

$\mathrm{v}(\mathrm{t})$ - tram speed and

$\mathrm{r}[\mathrm{v}(\mathrm{t})]$ is the resistance encountered by the tram due to frictional forces.

\section{A. The initial result.}

By analyzing the profile for a train traffic, in the same way, we notice on the tram, that for a distance between two stations " $\mathrm{X}$ " and the corresponding time to cover this distance " $\mathrm{T}$ ", we have 3 phases, namely: maximum acceleration phase, phase in which switches to inertia and in which the speed decreases slightly and the maximum braking phase with stopping at the next station, according to Fig. 3 (Howlett \& Pudney, 1994).

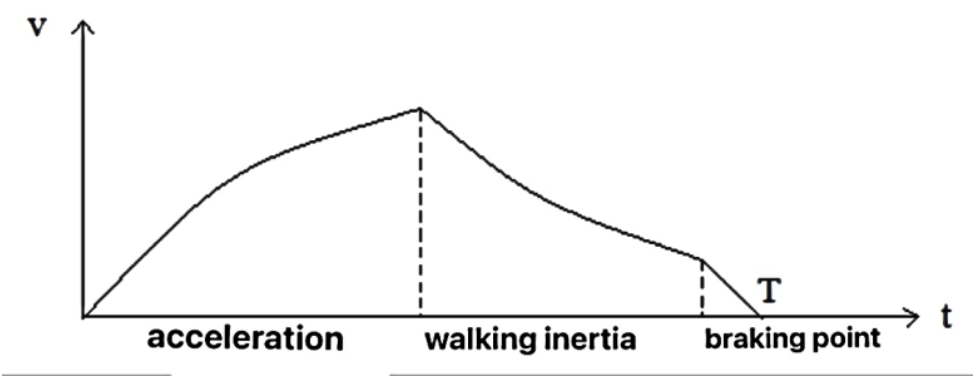

Fig. 3. Acceleration profile- inertia-travel braking. Source: Howlett \& Pudney (1994)

B. Advanced result. Compared to the 3 phases, in order to obtain an optimal driving strategy, an additional phase is introduced after the maximum acceleration phase, which consists in maintaining a constant speed if the travel time is sufficient, so that for a distance between two stations " $\mathrm{X}$ " and the corresponding time to cover this distance " $\mathrm{T}$ ", we have 4 phases, namely: the maximum acceleration phase, the phase in which you drive at a constant speed, the phase in which you go from inertia and in which the speed decreases slightly and the phase of maximum braking with a stop at the next station, according to Fig.4 (Howlett \& Pudney, 1994). 


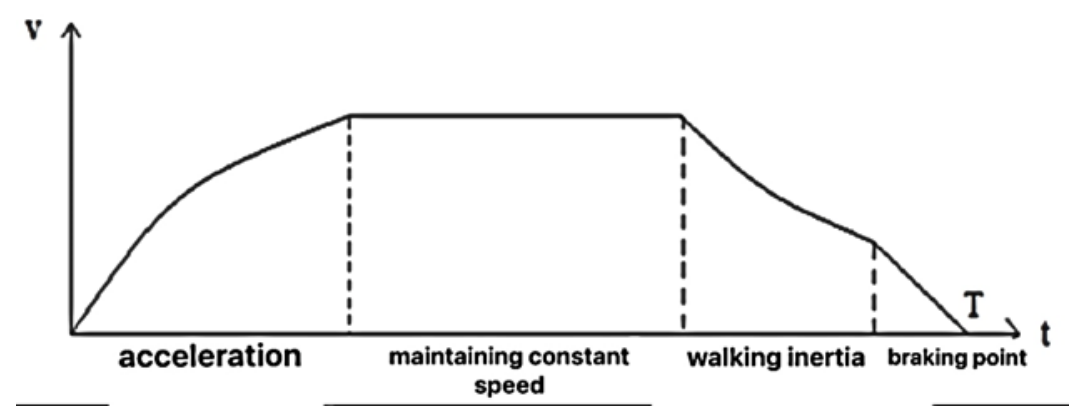

Fig. 4. Acceleration profile-constant speed driving-inertia driving-braking Source: Howlett \& Pudney (1994).

\section{Control device}

The control device aims to reduce energy consumption and is based on a well-established schedule between 2 consecutive stops. The timetable specifies the time of arrival at each station and a strategy for driving the tram that allows it to fit into the requested schedule as efficiently as possible.

For each travel segment, which has a length between $400-500 \mathrm{~m}$, the acceleration - inertia - braking strategy is the most efficient, but problems arise when it is necessary to accurately determine the transition from one phase to another, because this would be difficult to achieve even for highly experienced drivers.

Walking in inertia depends on the time left to complete the segment to the next station and the speed of the tram. Moreover, the small-time changes in which the inertia gait occurs can generate changes in the program at the next stop.

If the inertial phase (f2) occurs 5 minutes earlier (at point $\mathrm{C}$ ), then the point between these phases moves forward by $\Delta \mathrm{d}=67.5 \mathrm{~m}(13.5 \mathrm{~m} / \mathrm{s}$ x $5 \mathrm{~s}=67.5 \mathrm{~m})$, and the tram reaches the speed at which it passes in the braking phase by $67.5 \mathrm{~m}$ (point D), compared to the desired point, so the speed of the tram is less than $5 \mathrm{~m}$ / s (point B), and the tram will take another $13.5 \mathrm{~s}(67.5 \mathrm{~m}: 5 \mathrm{~m} / \mathrm{s})$ to obtain to the point where it had to pull in the braking phase ( f3).

The effect is to increase the travel time by $8.5 \mathrm{~s}$, and the tram reaches the next station (station B) delayed by $8.5 \mathrm{~s}$. At a number of 16 stops, a delay of about 2 min 16 seconds is obtained $(16 \times 8.5 \mathrm{~s})$, so an exact approximation involving the human factor, when the transition from one phase to another involves a braking with a decrease in the phase of inertia, in both cases resulting in additional energy consumption. It is thus necessary, depending on the space and time coordinates needed to cover the distance between the two stops, as well as the speed, the exact indication of the phases in the sense that it must be displayed and when the 3 phases must be maintained but especially the exact passage of a phase in the other (Howlett \& Pudney, 1994). 


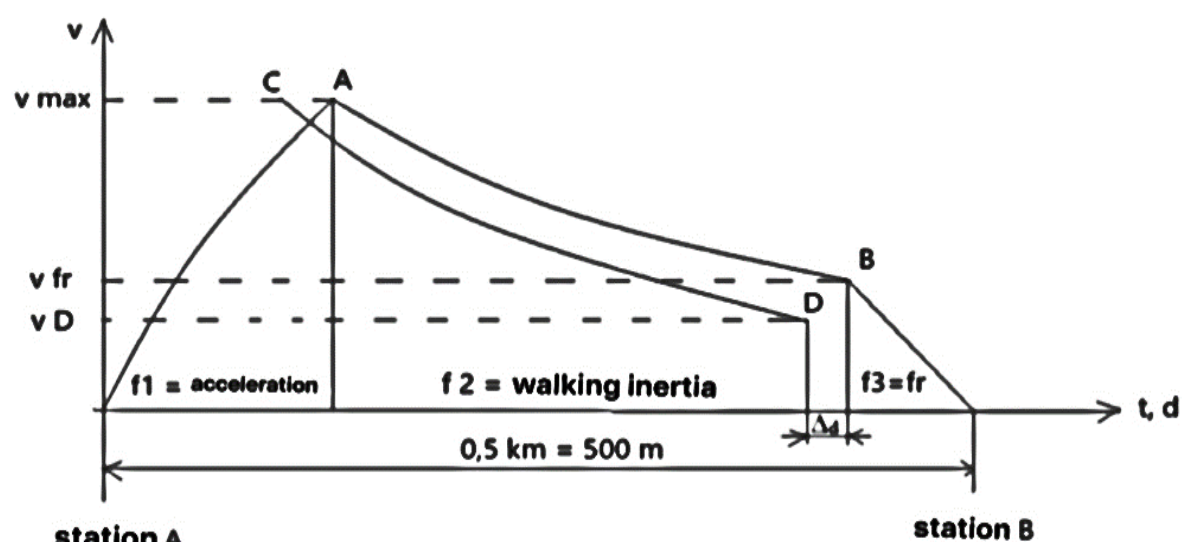

Fig. 2. Walking from inertia

Source: Howlett \& Pudney (1994)

The condition of the trip

In order for the tram to operate according to the established schedule with a minimum energy consumption, certain values must be followed and determined accurately:

- Current time and time left until the next stop;

- The position of the tram and the distance remaining until the next stop;

- Tram speed. Speed and distance are quantities that can be determined accurately, and stops and arrival times are entered into the program.

Tips on how to drive

The conclusions consist in:

- Braking must be performed at a specified time to avoid delay until the next stop.

- If the tram is able to go by inertia and brake when it reaches the scheduled time at the next stop.

\section{Braking decision}

The braking decision depends on the remaining distance to the next stop, the speed of the tram, the braking performance of the tram, the configuration of the railway (line slope, curves, etc.). (Howlett \& Pudney, 1994).

Braking performance depends on the negative acceleration rate " $K$ " for traction and the acceleration "ag" due to the slope of the line.

The distance required to stop the tram is:

$\mathrm{s}=\frac{\mathrm{v}^{2}}{2\left(\mathrm{~K}+\mathrm{a}_{\mathrm{g}}\right)}$

where " $v "$ is the speed of the tram. 
If we denote by $\mathrm{d}$ - the remaining distance to the next stop, then we distinguish two cases: (Howlett \& Pudney, 1994).

$\mathrm{s} \leq \mathrm{d}$, then the braking of the tram must not intervene.

$\mathrm{s} \geq \mathrm{d}$, then braking must be applied immediately.

The decision to go by inertia (second phase)

The decision to go through inertia is much more complex, because, like braking, it depends on the location, speed and performance of the tram to go through inertia. If the tram tends to arrive earlier, the inertia phase expands and if the tram is delayed, then this phase is reduced or even omitted. The inertial walking phase is strongly influenced by the profile of the section (slope with ramps and road slopes).

The performance of the tram to pass from inertia depends on the negative acceleration-needle ", which is influenced by the slope of the line, the resistance due to the friction and speed of the tram. An important feature of the control device is that the inertia performance is read automatically at each movement point and at any speed.

If it is considered that:

$\mathrm{t}$ - time remaining until the next stop,

$\mathrm{v}$ - tram speed,

vb- the speed at which the braking occurs, then the value of the negative acceleration '- ac' must be calculated in the inertia phase, so that the distance traveled in this phase has the value:

$\mathrm{S}_{\mathrm{c}} \frac{\mathrm{v}^{2}-\mathrm{v}_{\mathrm{b}}^{2}}{2 \mathrm{a}_{\mathrm{c}}}$

If it is considered that:

- tb - time remaining until the next stop in the braking phase,

- $\mathrm{db}$ - distance to the next stop in the braking phase,

- vb- the speed at which braking occurs $\mathrm{d}$ - the distance from the point where the train was to the next stop;

- then the braking distance has the value: (Howlett \& Pudney, 1994).

$\mathrm{d}_{\mathrm{b}}=\frac{\mathrm{v}_{\mathrm{b}}^{2}}{2\left(\mathrm{~K}+\mathrm{ag}_{\mathrm{g}}\right)}$

$\mathrm{d}_{\mathrm{b}}=\mathrm{d}-\mathrm{s}_{\mathrm{c}}$

and by eliminating the term $" \mathrm{v}_{\mathrm{b}}$ " it results

$\mathrm{d}_{\mathrm{b}}=\frac{2 \mathrm{a}_{\mathrm{c}} \mathrm{d}-\mathrm{v}^{2}}{2\left[\mathrm{a}_{\mathrm{c}}-\left(\mathrm{K}+\mathrm{ag}_{\mathrm{g}}\right)\right]}$

If $\mathrm{db}<0$, then the tram stops during idling before the next stop.

If $d b \geq 0$, then the tram speed at the time of braking is

$v_{b}=\sqrt{2\left(K+a_{g}\right)} d_{b}$ 
The duration of the braking phase is

$$
\tau_{\mathrm{b}}=\frac{\mathrm{v}_{\mathrm{b}}}{\mathrm{K}+\mathrm{a}_{\mathrm{g}}}
$$

The total time spent in the inertia and braking phase is:

$$
\tau=\tau_{\mathrm{b}}+\frac{\mathrm{v}_{\mathrm{b}}-\mathrm{v}}{\mathrm{a}_{\mathrm{c}}}
$$

if $t \geq \tau$, the tram can come out of inertia and reach the next stop before the scheduled arrival time (program).

if $\mathrm{t} \leq \tau$, the tram no longer passes through inertia and will arrive in time at the next station.

\section{E. Display of driving mode on the display}

The 3 phases of driving (acceleration, inertia and braking) are displayed with the appropriate lights on the display to advise the driver on how to drive, so that when the light corresponding to the acceleration phase is displayed, this state of the tram is maintained and indicates that it is early to move to the second phase of inertia and the tram runs at the allowed speed.

If the light changes from the acceleration phase to the inertia phase, then this indicates that it is possible to reach the next station at the set time with the help of the two phases of inertia and braking. Sometimes it is necessary to reduce the speed of the tram after moving from the acceleration phase to the operating phase from inertia, this means that the second phase is the delay is delayed and has no possibility to reach the next station at the scheduled time.

\section{F. Running times}

The method accurately calculates times and helps the tram reach the next station a few seconds earlier and a good schedule is needed to save energy. Each trip can be considered as a sequence between two stations. For each segment, the cost of an optimal control profile will decrease as the time available increases. The optimal program is needed to find the time segment that offers the total travel time with the lowest costs. The total time " $\mathrm{T}$ " is the sum of all times "Ti" for all segments.

\section{G. Test results}

If the driver was informed on the display about how to drive the tram, this led to a reduction in energy consumption on average by approx. 15-20\% compared to when he was not warned.

The economical driving of a tram depends on the driver's costs, on one hand, but it must also take into account speed restrictions that can lead to delays and additional consumption, weather conditions, etc.

As shown in Fig. 6, starting strongly with maximum acceleration, ensures, on one hand, the faster passage to the low-speed zone, where the efficiency of the locomotives is lower and, on the other hand, it has the necessary time reserve to 
reach the next station, passing through the inertia phase and the braking phase.

Performing slowly starts in the maximum acceleration phase after the $0-\mathrm{B}$ curve involves reducing the inertia phase, which is actually the most efficient form of energy recovery, as well as the need to perform braking at high speeds (from point B). The driving of the tram along the curve $0-\mathrm{B}$, followed by a high-speed braking is in fact an uneconomical driving as shown in fig.6 (Howlett \& Pudney, 1994)

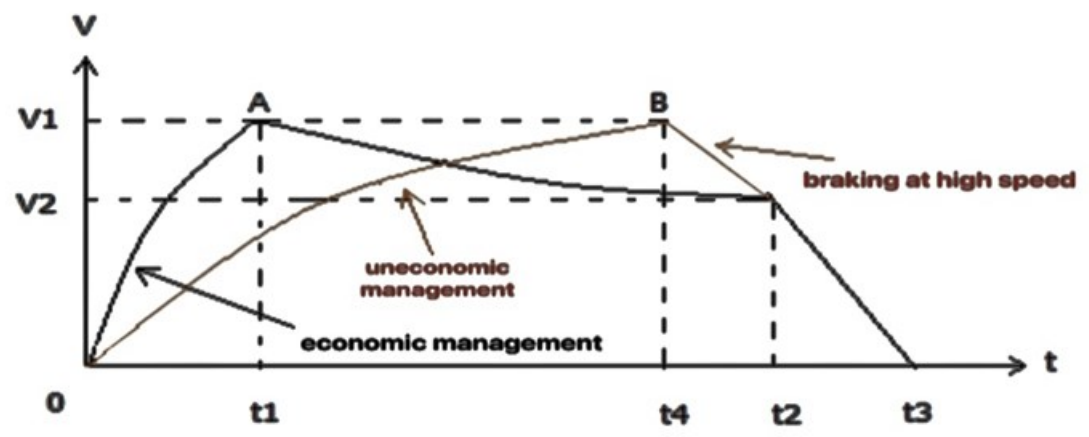

Fig. 6. Economic driving and non-economic driving Source: (Howlett \& Pudney, 1994)

It is also noticed that high speed braking is in fact an energy consumption and this consumption is all the more important the higher the braking starting speed (point B in Fig. 5) and, on the other hand, the braking time at a higher speed V1 increases compared to braking at a lower speed V2 until the train stops completely. Economic driving means first of all the dissipation by braking of a minimum amount of energy and this is achieved by the beginning of braking at a speed V2 lower than V1, so after a phase of inertia.

\section{Maintenance speed}

Maintaining a constant rate of electricity consumption helps maintain a constant speed related to a level of traction. However, the driver of the vehicle can approximate a constant speed strategy using control periods with a higher and lower rate of power supply through a gait consisting of inertia-acceleration gait.

Speed fluctuations are inefficient, because if the speed of the tram is too high, then the forward resistance increases and if the speed of the tram is too low, then the running time of the tram will be affected. Unnecessary braking at any stage of the journey will require another acceleration that involves additional energy consumption as well as a delay.

Crossing through central areas is often hampered by the large number of vehicles crossing intersections but also by drivers forcing these intersections. Parking cars on the first lane also make traffic difficult. To prevent these situations and streamline traffic, it needs to be controlled, by monitoring the entrances and exits to/from the central area, by displaying the number of cars at any time, so that drivers can be informed about this aspect and look for alternative routes, as well as 
by providing underground or surface parking lots. The peak hours are generally in the morning from 6.00 to 8.00 , when most work trips to the city center are made while the peak hours at exit are around 14:00h and 17:00-18:00h. There are also areas where many routes overlap on relatively long areas, i.e. there are bus lines overlapping onto trolleybus routes, and the only special corridors for means of public transport are only in a few areas such as in the area Pod Izvor-Piața Unirii, and for light-colored trams these help to optimize travel times if there are also unruly drivers in traffic entering this area (own source authors- photo gallery).

The solution should also be extended to the regional rail or metropolitan / regional transport system by creating a unitary public package of services to be joined by all carriers.

There are also speed restrictions, applied according to road traffic policy, in various areas of the city.

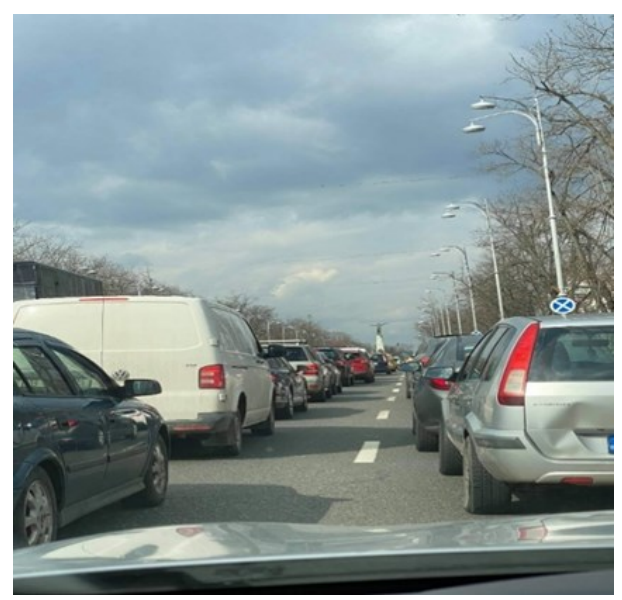

Fig. 7. Traffic at 8 am- Sector 2 Bucharest Fundeni Road. Source: authors' own photo gallery

Table 1. Speed limits in Bucharest.

\begin{tabular}{c|c|c}
\hline Type of street & Vehicle types & Speed limit \\
\hline Residential areas & Cars & $30 \mathrm{~km} / \mathrm{h}$ \\
\hline \multirow{2}{*}{$\begin{array}{c}\text { Main arterial roads, } \\
\text { avenues }\end{array}$} & Cars & $60 \mathrm{~km} / \mathrm{h}$ \\
\cline { 2 - 3 } & Trams, trolleybuses & $50 \mathrm{~km} / \mathrm{h}$ \\
\cline { 2 - 3 } & Cars & $50 \mathrm{~km} / \mathrm{h}$ \\
\hline \multirow{2}{*}{ Secondary street } & Trams, trolleybuses & $40-\mathrm{km} / \mathrm{h}$ \\
\cline { 2 - 3 } & Special Vehicle & $30 \mathrm{~km} / \mathrm{h}$ \\
\hline
\end{tabular}

Source: Ghidulrutier.eu

The variation of the traffic intensity in the city can change depending on the work schedule.

The use of public transport has an important effect in terms of reducing air and noise pollution, increasing the quality of life of city inhabitants and, at the same time, an attractive public transport system can discourage private car transport, with a positive effect in decongesting traffic and increasing road safety. It is necessary to 
renew the rolling stock in Bucharest with environmental-friendly means of transport with minimal negative effect on the inhabitants but also on the environment, contributing to the improved mobility of all passengers, including those with special needs, under comfortable conditions. The optimal management of public passenger transport reduces the time spent in traffic, thus increasing the time allocated to children's education, leisure, self-training, etc.

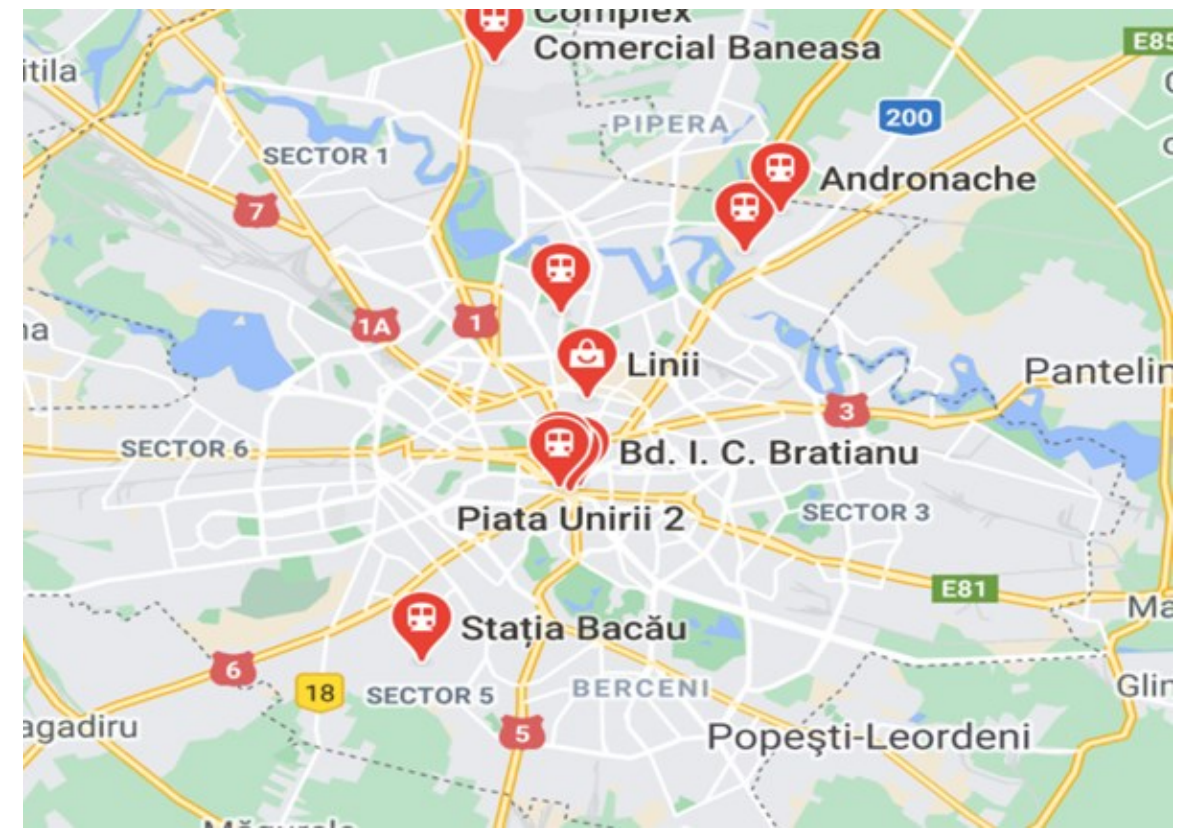

Fig. 8. STB S.A Map (Recomandări în perioada pandemiei, nd / Pandemic recommendations, n.d.)

Types of STB passenger transport documents - tickets (Societatea de transport Bucuresti (nd.).

- travel card for 1,2,10 journeys

-1-day ticket,

- monthly travel card: full value or $50 \%$ reduced value (school and university students, blood donors)

- weekly travel card (7 days) with unlimited number of passengers using it

- travel passes for persons protected by special laws/regulations

- METROREX -RATB common card

- single ticket for 60 minutes.

Compared, in Vienna, as a result of the investments made, the number of people using public transport on a daily basis has increased. The rates applied by wiena lines are:

- One travel ticket : 2,40 euro

- Card travel 24 hours : 8,00 euro 
- Card travel 48 hours : 14,10 euro

- Card travel 72 hours and weekly card travel : 17,10 euro (Săptămâna europeană a mobilității 2019)

In 2017, the metro was the most popular public transport type in Paris. That year more than 1.53 billion journeys were taken on the metro in the French capital. Paris had the highest number of metro stations in Europe in 2015, and the RATP Group, which is responsible for most of the public transport in Paris, welcomes tourists thrilling to discover the City of Lights, as well as Parisian in their everyday life (Statista Research Department, 2021).

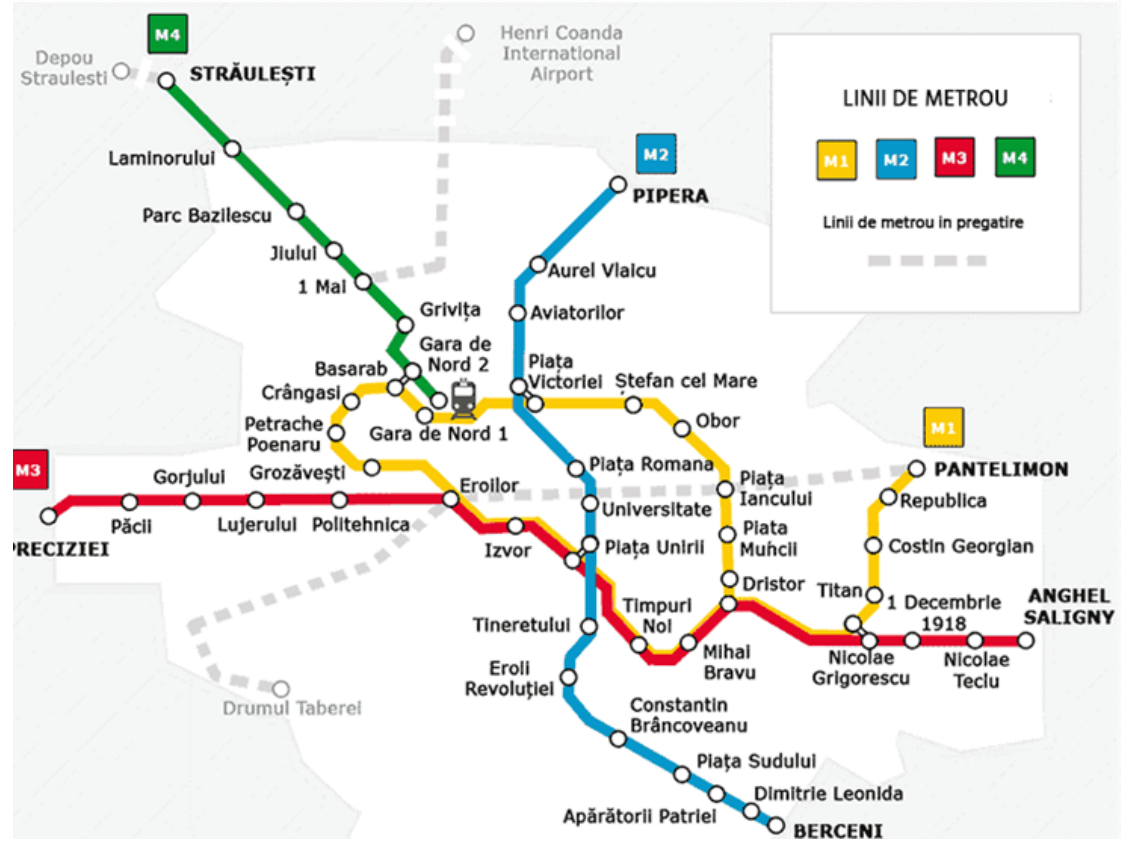

Fig. 9. Map of Metrorex S.A.

\section{Types of Metrorex travel documents (Metrorex (n.d.)}

- travel ticket valid for 2 or 10 journeys;

- 1 day-ticket,

- weekly travel card,

- monthly pass with unlimited number of trips,

- monthly pass with unlimited number of trips for students,

- METROREX-RATB common card.

The subway traffic in Bucharest is carried out at a frequency of arrival at stations (depending on the main function) between 5-10 minutes.

The reopening of the existing railway line surrounding Bucharest, i.e. Bucharest North-Pantelimon-Băneasa, as well as the repair of the Gradistea bridge on the route Bucharest North-Giurgiu North, Chitila-Bucharest South, can takeover the inbound traffic from Ilfov County, encouraging passengers to use the train instead of cars. In order to be able to change the route, it is necessary to change bus lines. 


\section{Geospatial information systems and traffic management}

In any public administration, the importance of information and communication technology cannot be ignored. Computer systems are designed to provide users with travel information. To solve traffic problems, some current application technologies can be indicated, such as:

- sensors located in the main arterial roads able to measure within the shortest possible time all the parameters related to the existing traffic: cameras, infrared sensors, electromagnetic sensors calculating with high accuracy the total number of vehicles (cars, trams, buses, trolleybuses, motorcycles) participating in that specific area traffic.

-access and availability to the location data of the traffic participants by means of the mobile phones;

-a sensor and an application analyzing the movement of all vehicles depending on their speed, distance, time and number, to help traffic participants through a permissive traffic light so as to streamline traffic where the number of vehicles is more prone to possible bottlenecks;

- supporting communication systems, designing road infrastructure, developing road signs;

- transmission by GPS data of the sections with congested or blocked traffic and offering advantageous alternative routes, with fewer traffic participants, and combining all traffic data so as to provide the traffic participant with the optimal solution for him.

These technologies are already implemented by some public administrations. Road authorities or even private operators providing services related to traffic travel, cope with difficulties in terms of high implementation costs, data volumes and charging new tolls.

\section{Assessing the traffic volume by means of data delivered by mobile data operators}

A significant amount of data is processed in the computer system of any mobile operator, based on which the speed of movement of vehicles along the arterial roads can be determined. Accurately determining the position of a mobile phone of the traffic participant given the signal strength helps to accurately provide the data to be processed. Identifying traffic jams by this method has the advantage of not requiring additional infrastructure investments, for which only the mobile telephony infrastructure is used (Fraser, 2007)

\section{Automatic identification of vehicles using RFID}

Radio frequency RFID (Radio Frequency Identification) technology, together with the global GPS positioning system, is used in transport to increase the accuracy of vehicle identification in Bucharest and related areas. They consist of: three readers, data transmission system and a processing system of data. In Bucharest, STB has a passenger information system regarding the estimated routes and waiting times until the vehicles arrive at the station - InfoSTB Android and IOS 
- shows the STB surface public transport routes and helps to choose a route to the desired destination. The application allows the passenger to find an optimal route between the "Departure point A" and the "Arrival point B" using the vehicles on the route and information about their positions. The application is only functional if the user allows the application to access the phone's location, being operable only for devices with Android operating systems version 5 or higher and iOS version greater than or equal to 10 . Improvements to current technologies such as the individual position of vehicles are needed to be identifiable by taking over and processing all data on the space, speed, time and distance of traffic participants. Once these improvements are made, the data received by this radio infrastructure will be consumed by computer systems, components of an integrated traffic management platform: a system for identifying and warning of traffic jams or areas where traffic is slow, a tax system for low-pollution class vehicles; providing traffic participants with the necessary information according to their needs (parking, refueling, various services, etc.). By adding improvements and implementing fiscal policies, traffic can be managed by improving the movement patterns of vehicles based on information received in real time, applying a tax for highly pollutant vehicles, while helping the traffic management system from tax revenues.

\section{Interconnection of public transport in Bucharest}

In Bucharest there are intermodal nodes but there is no reliable service to inform passengers about all the possible connections between modes of transport, and their traffic schedule in relation not only to the current station but to other stations as well. For this, we propose the following study in order to establish the optimal transport time, as well as the idle time while transferring from one mode of transport to another. It starts at point A over a distance of $12 \mathrm{~km}$. For this, three modes of public transport will be selected - the subway, the tram and the bus.

The time selected as departure time from the metro station Gara de Nord Dristor 2 will be 17:46h. To change route, it is necessary to change the bus line.

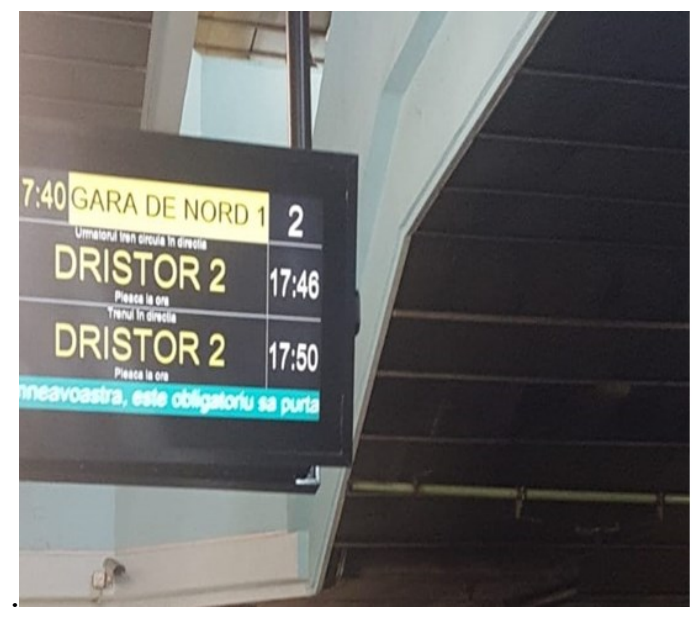

Fig. 10. Subway North Station.

Source: authors' own photo gallery 
After a $1.5 \mathrm{~km}$ journey in less than 2 minutes, the first stop/transfer will take place in Victoriei Square subway station and the crossing to the main line 2 will be made by means of escalators.

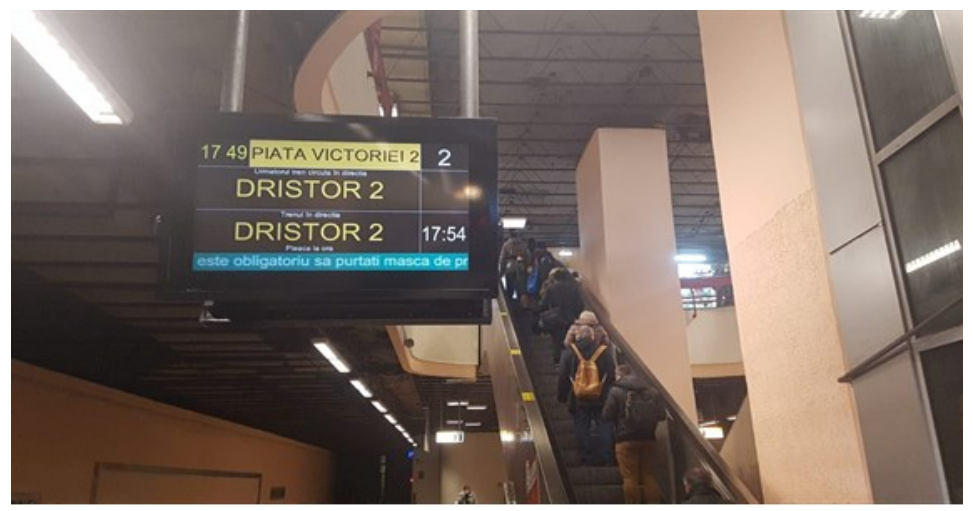

Fig. 3. Victoriei Square subway

Source: authors' own photo gallery

The arrival time at the next subway station within Victoriei Square subway hub in the direction of Berceni is 17:58, and the number of stops to cover in order to change the mode of transport (by tram) are Piaţa Romană-Universitate-Piața Unirii 2-Tineretului and the final station is the Piata Eroii Revoluției, travel time of 10 minutes. To get to the tram station Piata Eroii Revoluției, you need a travel time of 10 minutes, including the waiting time at the pedestrian crossing.
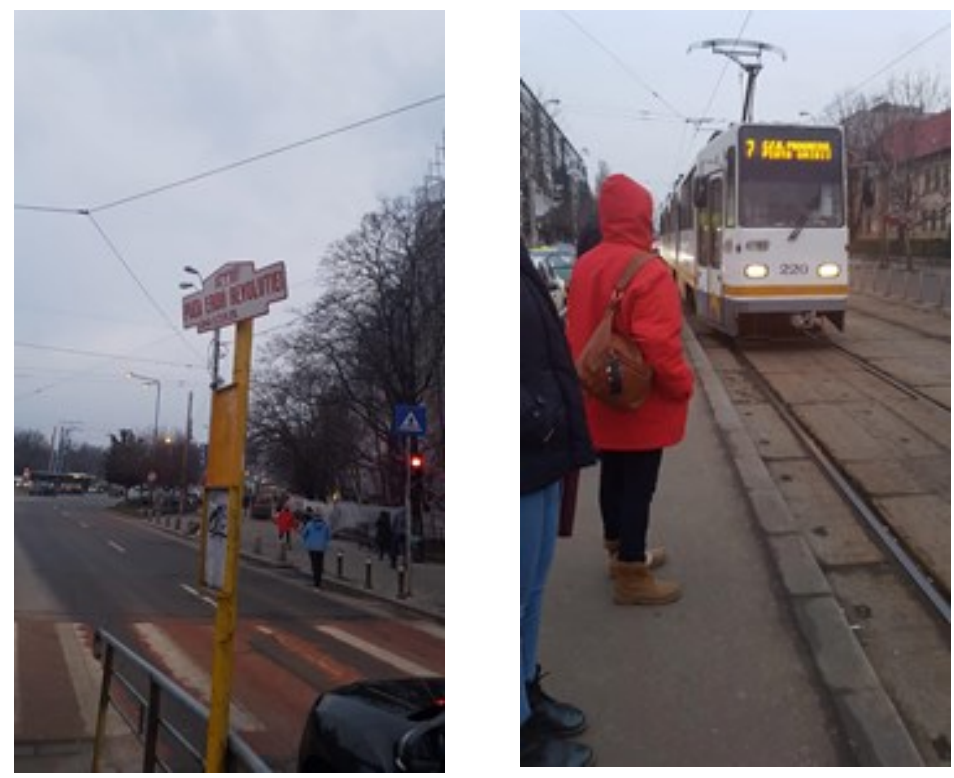

Fig. 12. Tram Station Eroii Revolutiei

Source: authors' own photo gallery

It can be noticed that there is no information panel displaying on the route and arrival time of the tram at the station. The station platforms are narrow, which 
means that passengers must be particularly careful when getting off the tram or waiting for it on the platform. The continuation of the trip by tram number 7 will be performed on the CFR Progresu route so that 5 stops will be covered until the Drumul Găzarului station, a route that will be take 10 minutes time.

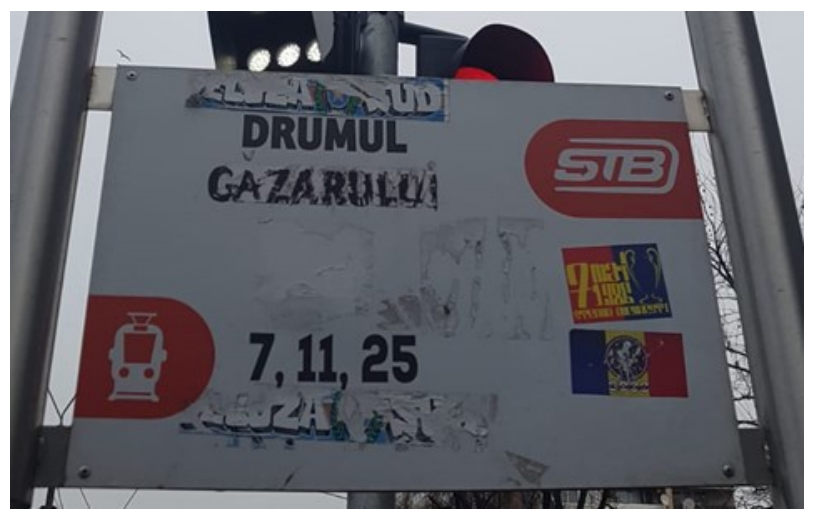

Fig. 13. Tram station Drumul Gazarului

Source: authors' own photo gallery

The tram route ends in Reşiţa Square, so the continuation of the journey will require yet another means of transport, namely the bus to Luica station, and this section of the journey will take another 14 minutes. The rest of the journey until the destination, i.e. Resita Square, will be made by walking.

\section{Public transport in Rome}

Just like in Bucharest, the traffic in Rome can be very congested during peak hours, both in the morning during work or school commute and in the afternoon and evening upon return.

The management of public passenger transport services in Rome is provided by ATAC (ATAC (Agenzia dei Trasporti Autoferrotranviari del Comune di Roma) - the Railway, Tram and Road Transport Agency of the Commune of Rome. subway.

The public transport system in Rome consists of buses, trolleybuses, trams,

The passenger information system is very well organized, so that travel times can be accurately estimated.

Bus traffic covers the entire city. Their circulation program is displayed on both classic and electronic panels. The electronic information panels announce the arrival time of the bus according to fig. 15. Like Bucharest, there are few parking spaces, and cars are parked on the first lane. 

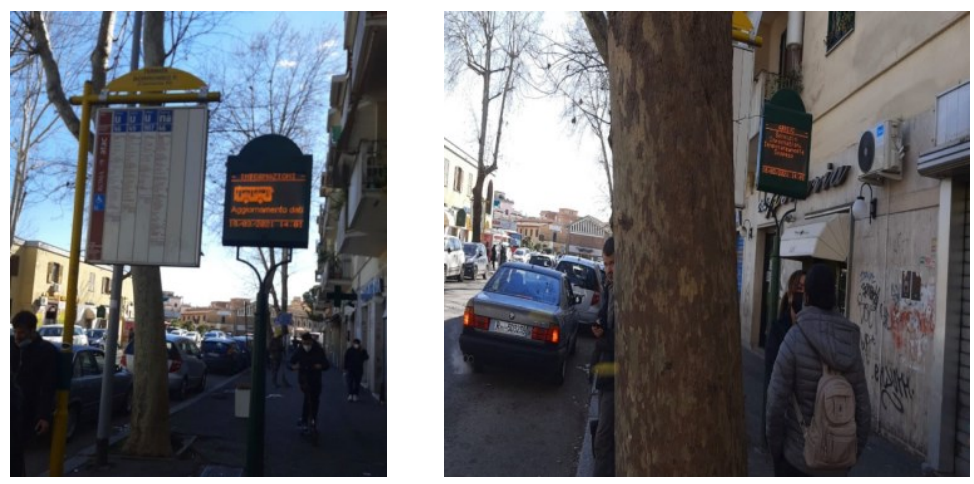

Fig. 4. Primavalle Pasquale bus station

Source: authors' own photo gallery

A case study will be carried out to cover a distance of $45 \mathrm{~km}$, having as departure point the bus station of Primavale PasqualeII, and two modes of bus transport will be subsequently used, namely subway $\mathrm{A}$ and subway $\mathrm{C}$, as there is no train sevice available as mode of urban travel. The transfer from one mode of transport to another, i.e. bus-subway, is made immediately by crossing a street from where one can board Subway A - Battistini (starting station) route for a number of 16 stops. Information regarding the arrival times of the subway at the station is electronically displayed, like in Bucharest.

After the 13 stops distance, it will ne necessary to cross 3 streets, because the underground passage that used to allow transfer to the Subway $\mathrm{C}$ line is closed for the duration of the SARS-COv 19 pandemic. (Societatea de transport Bucuresti, nd.). The journey by Subway line C, which has been operating for several years, will cover 10 stations to Giardinetti station. Subway line $\mathrm{C}$ is modernized and the access to the subway station greets you with a place arranged for a museum. The platform is secured with doors, so boarding the subway can only be done when the train stops in the station and the doors platform will open. The platform in the subway station is protected by glass doors, so that the access to the metro can only take place when the train stops in the station. The subway train runs driverless, and the traffic management is provided by a traffic controller, with the information being transmitted by loadspeaker system and displayed simultaneosly on the station monitors (Fig.15).
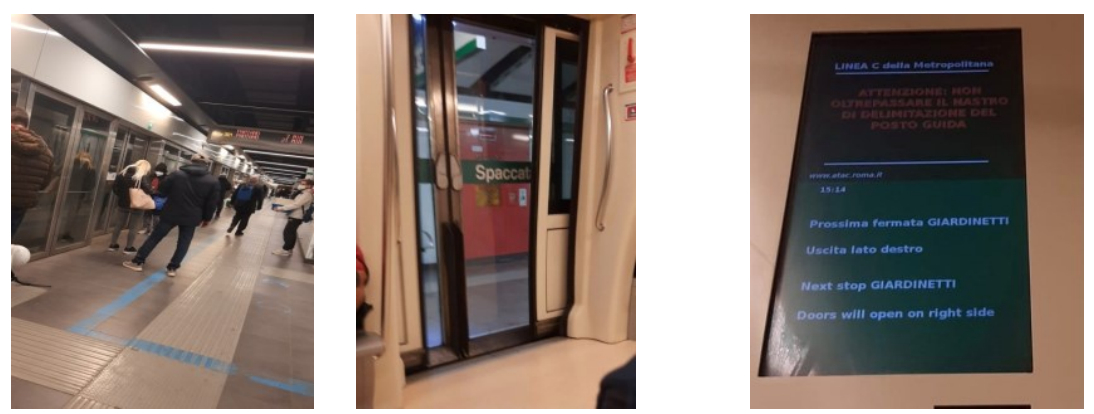

Fig. 15. Subway C station Giardenetti -Rome \& Subway information panel. Source: authors' own photo gallery 


\section{Intelligent transport systems}

Intelligent transport systems (ITS) are transport systems that use the information and communication technology needed to streamline and increase the quality of transport services (traffic management and public transport management). One of the main objectives of ITS is to monitor and control traffic conditions. (Anand et al., 2017).

These can be defined as functional areas:

- traffic management,

- informing all traffic participants,

- navigation support,

- assistance for traffic operations and emergencies.

The scheme of operation of an ITS is derived mainly from the classical diagrams defining systems in computer science(Fig. 16).

In the case of urban traffic in the Bucharest-Ilfov area, a series of systems have been introduced to improve the flow and increase traffic safety, as well as subsystems oriented towards regulation, organization and supervision to monitor the working conditions of vehicle drivers, but also to impose speed limits. During the period when the Romanian company UTI implemented the traffic management system in Bucharest, it covered 96 intersections, and then it was extended to 270 intersections out of a total of 450. (BUCUREŞTI, România - Sistem integrat de management al traficului(n.d.).

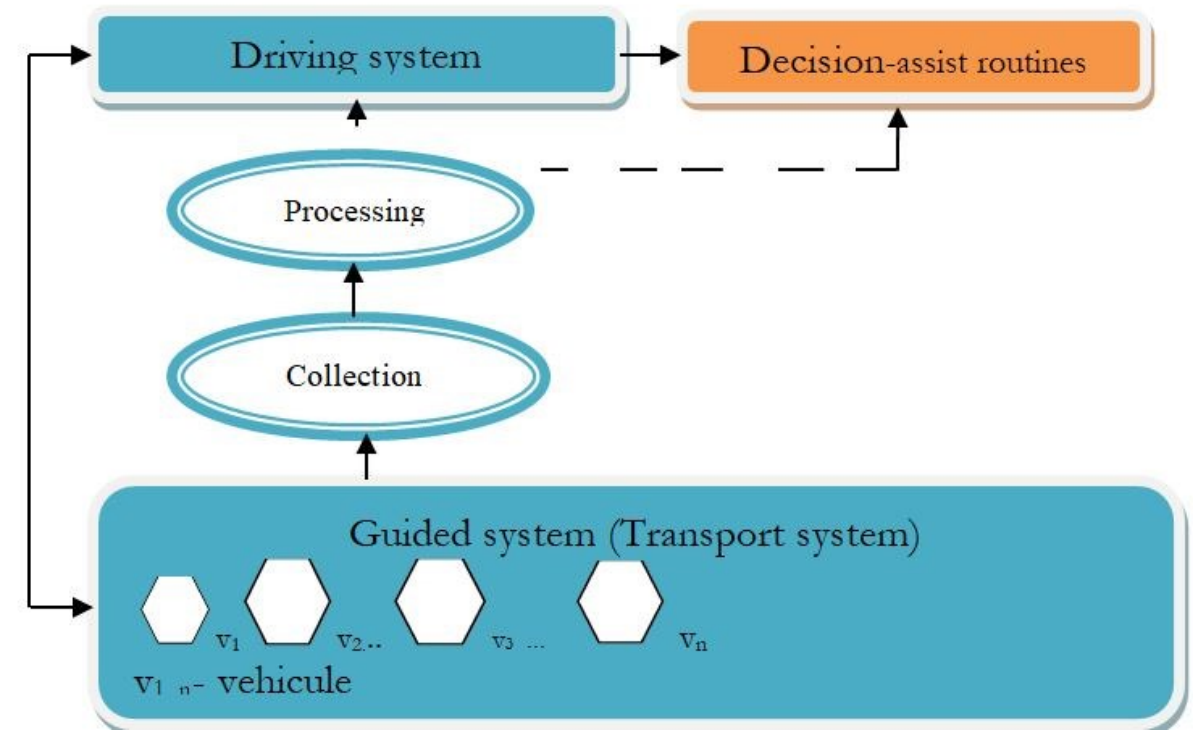

Fig. 16. Functional diagram of an intelligent transport system Source: BUCUREŞTI, România - Sistem integrat de management al traficului(nd.)

Advanced traffic light systems that show the waiting time in red greatly reduce the stress of road users, but also contribute to increasing road safety.

There are different types of intelligent transport systems, including:

- Emergency Management Systems (EMS) - systems that aim to coordinate 
human and technical resources to deal with emergencies and restore roads if blocked or damaged.

- Advanced Vehicle Control Systems (AVCS);

- Commercial Vehicle Operations Systems (CVO);

- Traffic security systems;

- Advanced Traffic Management Systems (ATMS)

All of these are transport management systems with the main purpose to ensure urban traffic control and monitoring, as well as other transport systems. ATMS systems are implemented in all transmission networks according to their individual specifications and functions.

In the case of road transport, ATMS performs other functions that contribute to the safety, comfort and quality of transport. It can provide information to passengers, support to reduce travel times, response times to possible incidents, and avoid traffic congestion. The efficient use of intelligent transport systems requires the integration of the technologies used to inform the traffic operator, the control of traffic vehicles and the IT procedures to help traffic management decisions. From a system perspective, SIT operates with the following categories of information:

a) Inputs

- information about traffic routes (streets, intersections, etc.);

- vehicle location information;

- information about travel directions (routes with the name of the station and streets);

- information about important events during the trip (accidents, traffic jams, vehicle immobilizations, etc.);

- traffic safety information;

b) Outputs

- predefined information for informing travellers;

- information for the vehicle drivers;

- information for carriers;

- information for decision makers at different levels (information required in managerial decisions).

The transformation structure (T), (actually, information processing procedures and obtaining the desired results), is based on information and communication technology and, in accordance with the objectives, it defines the type of intelligent transport system.

\section{Efficient passenger information systems}

In traffic management systems, passenger information subsystems play a special role. In the literature, subsystems are themselves regarded as independent systems, but are directly related to ATMS (ATIS- Advanced Traveler Information System. 


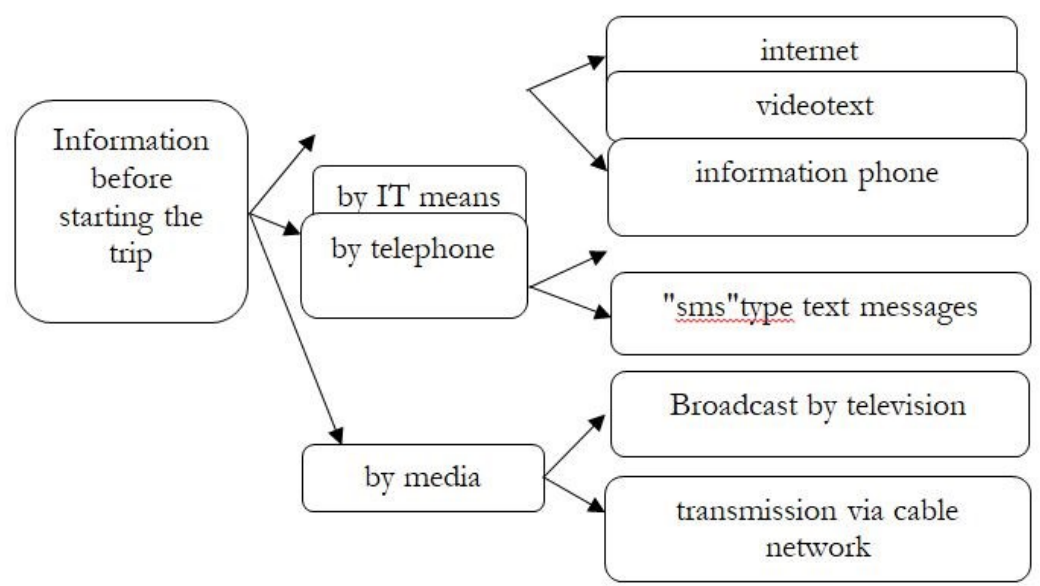

Fig. 17. Ways to inform passengers before starting the trip Source: Fraser (2007)

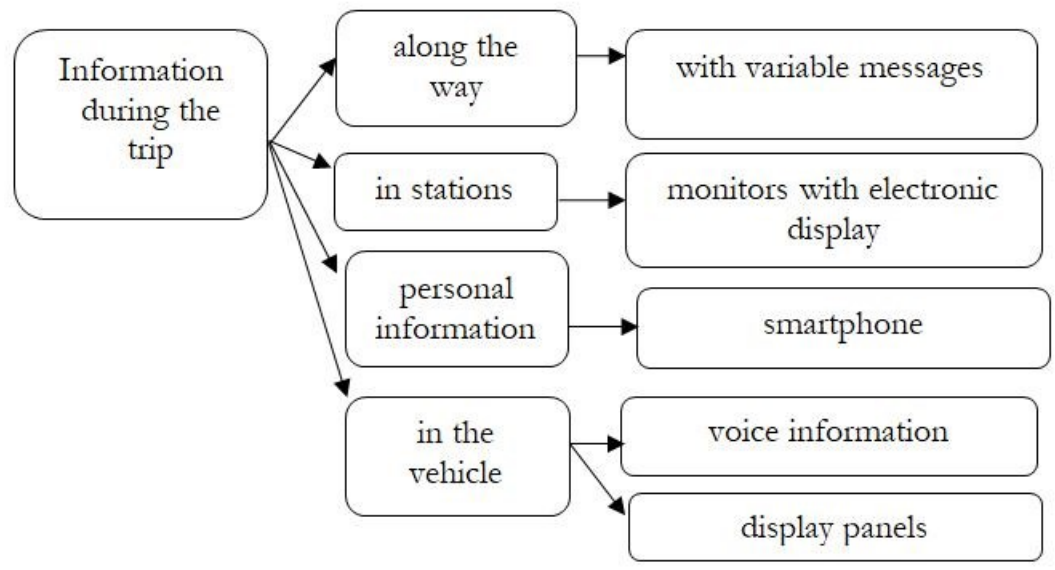

Fig. 18. Passenger information modes for transport services during the trip Source: Fraser (2007)

The traffic monitoring centers and transport management systems concerned.

The main requirements of ATIS (ATIS-Advanced Traveler Information System) are aimed at:

a) passengers

- planning the trip in multimodal transport if the traveler needs several types of means of transport to reach the destination;

- informing passengers about incidents or delays;

- remaining or estimated travel time to the destination;

- time left until the next multimodal connection;

- information on compliance with the estimated duration of the trip; 
- information on the charging system and the cost of travel by other means of transport, if the passenger chooses to continue the route by other means.

b) operators and managers:

- "on-line" guidance of the vehicle on the transport route;

- information about unfavorable traffic conditions (road condition, traffic jams, etc.);

- information on restricted roads

- information about parking lots and their occupancy status;

c) managers

- transport system managers have access to all types of information presented above in order to manage passenger traffic and transport as efficiently as possible.

Methods and means of information for travelers are constantly evolving regardless of how the trip is conducted, seeking to find those solutions that provide the most up-to-date data. Complementary alternatives to urban transport are being discussed more and more.

The most promoted, analyzed and sometimes controversial is the alternative to private urban transport. In this respect, two aspects are considered:

-privatization of a certain route, with the full takeover of the activities specific to urban transport;

-continuation and development of the existing partnership by a private operator.

The choice of transport routes is particularly important, offering various alternatives with direct effects on the duration of transport, the costs of transport and passenger safety. The information provided to passengers is all the more complete as the volume of information is integrated into the entire transport.

Members states are also invited to continue their legislative efforts on intelligent transport systems (ITS), which could help increase transport efficiency, reduce $\mathrm{CO} 2$ emissions, improve air quality and reduce noise pollution. According to Eurobarometer 406, published in 2013 half European citizens use their personal cars every day, while public transport is used by only $16 \%$ of citizens and bicycles by only $12 \%$. (Săptămâna europeană a mobilității 2019)

\section{Models of organizing traffic management in Bucharest-Ilfov (CCTV)}

Traffic management through SIT systems can be performed in a concentrated, distributed or mixed system (i.e. a number of concentrated services, while others are distributed). Concentrated traffic management systems involve the existence of a single traffic management center where all traffic information is collected. Decentralized traffic management systems are systems that operate per type of transport (subway, car, tram, etc.). The UTC subsystem is adaptive (SPOT UTOPIA), but it should also allow real-time coordination of traffic light times according to traffic flows. This operation is performed by vehicle detection devices, which are in constant circulation, the data being transmitted to the traffic control 
center via a fiber optic network. SPOT - UTOPIA systems are versatile. These systems can allow traffic lights to be adaptive and operate both locally but also transmit information to intersections and the control center. (Primaria Municipiului Bucuresti. Directia De Transporturi Drumuri si Sistematizarea Circulatiei, 2017)

Mixed traffic management systems consist of the centralized approach for a number of services (usually services of interest for several types of transport networks, transport route situation measurement services, traffic incidents, etc.) and decentralized approach for services specific to a certain type of transport. Smart traffic lights are a new concept that brings a lot of benefits in terms of traffic with priority for public transport being one of the solutions to be considered.

\section{Recommendation}

Following the presentation of the transport mode at the level of European capital and for the improvement of the public transport optimization mode, the following recommendations can be made:

- construction of a major intermodal station in the key area of Bucharest that can be integrated so that transfer from one mode of transport to another can be easily made;

- bike lanes/tracks;

- purchase of trams fitted with GIS system, as well as environmentfriently/electric buses that will contribute to the reduction of pollutants/ particulate matters, as well as less noise for the city inhabitants;

- installing information panels in tram and bus stations for passengers, in order to assist in estimations of the trip times and waiting time in the station;

- extension of the tram electified network;

- subway platform security system;

- to continue the journey by other modes of transport or on different routes, they may have the same arrival points. In case of change of public transport modes, to reduce the waiting times for passengers in the stations where these transport modes overlap, it is necessary that the arrival and departure times be as close as possible, and the schedule of the different means of transport at the intersections be correlated;

- renewal of the tram fleet in order to offer passengers more information about the selected route (duration of the trip, traffic flow), possibilities of choosing and changing the transport mode to reach other destinations;

- increasing the accessibility of all persons, in particular persons with special needs in every public transport mode, so that this category of passengers can also benefit from public transport;

- improving the safety and security in stations, as well as tram lines by installing delimitation panels between car and rail transport, so that cars are not allowed to enter the area designed for tram traffic, given that rail traffic has priority over cars, according to the legislation and for this reason it is even faster. The space for tram traffic can be used in exceptional cases for ambulances, firefighters and special missions and to avoid roadblocks. 


\section{Conclusions}

The public transport service is absolutely necessary as it represent the basis of mobility and access to urban facilities.

The Bucharest-Ilfov region benefits from an infrastructure network that must be adapted for multimodal public transport, which implies financial sustainability for modernization, maintenance and investigations, and this sustainability is currently affected by the rigid separation between transport modes and transport operators.

In Bucharest, the metro, tram, trolleybus and bus network services provided by public operators (STB and METROREX) must be expanded and integrated into an intermodal public transport system.

The digitalization and implementation of an integrated concept of multimodal public transport system will reduce operating costs, make the transport system more efficient and increase passenger mobility, creating the premises for a sustainable system.

Being a complex service of economic interest, the basis of mobility and access to urban facilities, it is necessary for the public passenger transport service to be modern in order to respond to situations of urban overcrowding due to traffic or passengers.

The intelligent transport system aims to monitor the traffic of all transport modes, provide timely information to passengers in order to be able to estimate travel times, delays and deviations from traffic schedule predetermined for various reasons of the means of transport used, affecting connections with other means predetermined transport conditions for making the trip and anticipating problems related to traffic jams. Monitoring of congested traffic areas should be carried out with priority in order to be able to identify in the shortest possible time any blockage with subsequent implications on the duration of the trip, fuel and energy consumption and implicitly the increase of pollution. If the car driver would adopt a driving style in traffic similar to the tram, characterized by a maximum acceleration regime, followed by constant speed driving and inertia driving, after which a slight braking effect will reduce energy or fuel consumption.

It is known that the immediate departures of a vehicle are the biggest consumers of energy or fuel, because the traction force is high (strong), and the more frequent these starts and departures lead to additional energy / fuel consumption with cost implications. All this data is possible by installing traffic surveillance cameras in all transport nodes, access to GPS data and monitoring as much as possible all traffic participants to obtain a clear picture of the overall transport.

Given the fact that in car transport, the first traffic lane on most streets in both directions has become a parking space for vehicles, resulting in losing this lane for car traffic, it would be appropriate to identify spaces for building above-ground parking lots and releasing these lanes, thus gaining space for car transport.

The extension of the tram transport network would represent an advantageous solution, considering that it has its own road being affected as little as 
possible by car traffic and could cover the areas of interest for passengers.

\section{Acknowledgment}

This paper was financed by the European Social Fund from the Human Capital Sectoral Operational Program 2014-2020, through the Financial Agreement entitled "Scholarships for entrepreneurial education among doctoral students and postdoctoral researchers (Be Entrepreneur!)", Contract no. . 51680 / 09.07.2019 SMIS Code: 124539 .

\section{References}

Agentia pentru Dezvoltare Regionala Bucuresti Ilfov (2020). Prezentarea regiunii [Presentation of the region]. https://www.adrbi.ro/despre-noi/regiunea-bucurestiilfov/prezentarea-regiunii

Anand, P., Alfred, D., Naveen, C., \& Seungmin, R. (2017). Intelligent transportation systems. In C. Naveen, D. Alfred, P. Anand \& R. Seungmin (Eds.), Intelligent Vehicular Networks and Communications (pp. 21-41). Elsevier.

Bucharest metropolitan area. https://www.google.ro/maps/place/Zona+metropolitană+București/@444.41033 39,26.0650789,9z/data $=! 4 \mathrm{~m} 2 ! 3 \mathrm{~m} 1 ! 1 \mathrm{~s} 0 \times 40 \mathrm{~b} 1 \mathrm{ff} 45 \mathrm{c} 9206 \mathrm{a} 31: 0 \times 278302 \mathrm{~d} 3 \mathrm{bf} 63978 ? \mathrm{hl}=$ ro

BUCUREŞTI, România - Sistem integrat de management al traficului [BUCHAREST, Romania - Integrated traffic management system].(n.d.). UTi. Retrived October 25, 2020 from https://www.uti.eu.com/linii-business/solutii-inteligentetransport/management-trafic-urban/portofoliu/bucuresti-romania-sistem-integratde-management-al-traficului/

Fraser, S. (2007). The Use of Floating Cellular Telephone Data for Real-Time Trans-portation Incident Management. McMaster University, Hamilton.

Ghidulrutier.eu. Categorii de vehicule [Vehicle categories]. http://ghidulrutier.eu/categorii autovehicule.htm

Howlett, G. \& Pudney, J. (1994). Energy efficient train control and Railroads, Automatic train control. Control Engineering Practice 2(2), 193-200.

https://doi.org/10.1016/0967-0661(94)90198-8

Metrorex (nd). Titluri de calatorie-tarife http://www.metrorex.ro/titluri de calatorietarife p1382-1 vizitat la 12.03.2021

Metrorex (2018). Raport Activitate METROREX http://www.metrorex.ro/Resurse/RaportActivitate/METROREX\%20rom\%2020 $\underline{18}$.

Parliament of Romania. (2001). Lege nr.351 din 24 iulie privind aprobarea Planului de amenajare a teritoriului national [Law no. 351 of July 24, 2001 on the approval of the National Spatial Plan]. Monitorul Oficial al României, 408, 2001, July 24. https://lege5.ro/Gratuit/gmztgobx/legea-nr-351-2001-privind-aprobarea-planuluide-amenajare-a-teritoriului-national-sectiunea-a-iv-a-reteaua-de-localitati

Primaria Municipiului Bucuresti. Directia De Transporturi Drumuri si Sistematizarea Circulatiei (2017). Sistemul de Management al Traficului din Bucuresti. [ Traffic 
Management System in Bucharest] https://smartcitiesofromania.ro/wpcontent/uploads/2017/02/2015-11.pdf

Săptămâna europeană a mobilității 201916 - 22 septembrie 2019 [European Mobility Week 201916 - 22 September 2019.].

https://www.dspsv.ro/uploads/PromovareaSanatatii/Mobilitate $\% 202019 /$ Analiza $\% 20 \mathrm{de} \% 20$ situatie $\% 20-\% 20$ Saptamana $\% 20$ Europeana $\% 20 \mathrm{a} \% 20$ Mobilitatii.pdf

Societatea de transport Bucuresti (nd.). Recomandări în perioada pandemiei / Pandemic recommendations). Retrieved March 14, 2021 from http://www.stbsa.ro/

Statista Research Department, (2021). Number of public transport users in Paris in 2017, by type of transit. https://www.statista.com/statistics/612773/paris-public-transport-usersby-transit-type/

Viena acum pentru totdeauna. https://www.wien.info/ro/hoteluri-transport- $\%$ C5\% $\%$ Fiindica $\%$ C $5 \%$ A 3 ii-practice/transport- $\%$ C3\%AEn-comun $/$ biletele- 361372 